\title{
O veto transverso de FHC à LDB: o ensino religioso nas escolas públicas
}

Luiz Antônio Cunha'

I- Professor da Faculdade de Educação

\section{Resumo}

Este artigo analisa o processo de reforma da Lei de Diretrizes e Bases da Educação Nacional-LDB (9.394/1996), pela Lei 9.475/1997, acerca do ensino religioso nas escolas públicas. Essa reforma foi desencadeada pelo veto transverso do presidente Fernando Henrique Cardoso, ao convidar o Congresso Nacional a proceder as mudanças na LDB, conforme as demandas da Conferência Nacional dos Bispos (Católicos) do Brasil. A principal fonte das informações foram o Diário da Câmara dos Deputados e o Diário do Senado Federal. Os argumentos de deputados e senadores a respeito dos temas em discussão foram postos em confronto, de modo a desenhar um panorama em que os defensores das demandas da Igreja Católica assumiram posição hegemônica. A principal demanda foi a supressão do impedimento de uso de recursos públicos para o ensino religioso nas escolas públicas, especificamente para o pagamento de professores. Cláusula desse tipo existia na primeira LDB, de 1961, mas fora suprimida em 1971, no auge da ditadura. Semelhante procedimento foi acionado em 1997, com igual sucesso. Além de mostrar as posições em confronto, o autor levanta hipóteses a respeito das razões que levaram à rápida mudança de posição dos partidos políticos. Além do financiamento, o autor focaliza a dimensão ideológica da reforma da LDB, especialmente a definição do ensino religioso como parte integrante da formação básica do cidadão. A conclusão do artigo foi que a reforma da LDB reduziu a autonomia do campo educacional no Brasil, por institucionalizar sua imbricação com o campo religioso.

\section{Palavras-chave}

LDB - Educação brasileira - Política educacional - Ensino religioso - Laicidade. 


\section{FHC's transverse veto to LDB: religious education in public schools}

Luiz Antônio Cunha'

I- Professor da Faculdade de Educação

da Universidade Federal do Rio de Janeiro, Rio de janeiro, RJ, Brasil. Contact: lacunha@globo.com

\begin{abstract}
This article analyzes the reform of Lei de Diretrizes e Bases da Educação Nacional (LDB - Law of Directives and Bases of National Education 9,394/1996), by Law 9,475/1997, regarding religious education in public schools. Such reform was triggered by the transverse veto of President Fernando Henrique Cardoso (FHC), who invited the National Congress to implement the changes in the $L D B$, according to the demands of the National Conference of the Brazilian [Catholic] Bishops. The main source of information were Diário da Câmara dos Deputados and Diário do Senado Federal (Journal of the House of Representatives and Journal of the Senate). The arguments of deputies and senators about the issues under discussion were confronted, which resulted in a panorama in which the defenders of the demands of the Catholic Church assumed a hegemonic position. Their main demand was the removal of the impediment to use public funds for religious education in public schools, specifically for the payment of teachers. Such clause existed in the first LDB (1961), but was abolished in 1971, at the height of the dictatorship. A similar procedure was adopted in 1997, with equal success. In addition to showing the positions in confrontation, the author raises hypotheses about the reasons for the rapid change in the positions of political parties. In addition to funding, the author focuses on the ideological dimension of the reform of $L D B$, especially the definition of religious education as an integral part of the basic training of citizens. The conclusion of the article is that the reform of $L D B$ reduced the autonomy of the educational field in Brazil by institutionalizing its overlap with the religious field.
\end{abstract}

\section{Keywords}

LDB - Brazilian education - Educational policy - Religious education - Secularism. 
A presença do ensino religioso nas escolas públicas de ensino fundamental foi determinada pela Constituição de 1988, após intensas disputas acerca do caráter laico da educação ministrada nos estabelecimentos oficiais. Em decorrência, a segunda Lei de Diretrizes e Bases da Educação Nacional - LDB/96 previu o ensino religioso como disciplina dos horários normais do ensino fundamental. Mas, os meios e os modos de seu oferecimento foram objeto de conflitos, nos quais a hegemonia política da Igreja Católica foi ostensivamente posta à prova, mas acabou por se afirmar.

Guardadas as devidas proporções, três décadas e meia depois de promulgada a primeira LDB (Lei 4.024, de 20 de dezembro de 1961), a segunda (Lei 9.394, de 20 de dezembro de 1996) retomou alguns dispositivos daquela e até mesmo foi objeto de similar reforma posterior. Em um deles, essa recorrência é evidente: a proibição do uso de recursos públicos no ensino religioso. Presente em ambas as leis, essa interdição foi substituída pela omissão complacente da legislação posterior, mais rapidamente na segunda do que na primeira.

Para uma análise da gestação do artigo acerca do ensino religioso nas escolas públicas, na $\mathrm{LDB} / 61$, remeto o leitor a Cunha; Fernandes (2012), que mostra como a restrição ao emprego de recursos públicos para o custeio dessa disciplina resultou de insólito acordo na Câmara dos Deputados, aceito pelo Senado e mantido no texto final sancionado pelo presidente João Goulart. 0 texto referido também esboça o contexto em que essa restrição foi suprimida da primeira LDB, em 1971, no auge da ditadura.

No que concerne à LDB/96, este texto baseou-se em arquivos de grupos de pesquisa, nos Diários da Câmara dos Deputados e do Senado Federal, além de entrevistas com deputados, senadores e consultores legislativos ${ }^{1}$.

1- Sou particularmente grato a Eva Waisros Pereira, pelo acesso ao precioso material do Centro de Documentação e Memória da Faculdade de Educação da Universidade de Brasília. Em seu nome agradeço, também, a outras pessoas que me ajudaram e que, por diversas razões, não foram mencionadas. Diante da impossibilidade de mencionar parte dos parlamentares e assessores entrevistados, optei por omitir seus nomes.
0 objetivo foi o de trazer ao debate elementos até agora inéditos, que permitam perceber os conflitos entre diferentes protagonistas, alguns já atuantes na Assembleia Nacional Constituinte de 1987/88.

A produção da LDB/96, no que se refere ao art. 33, isto é, ao ensino religioso nas escolas públicas, foi analisada em Cunha (2014), que mostrou os conflitos envolvidos na normatização dessa questão. Com efeito, o financiamento do ensino religioso nas escolas públicas foi o ponto nevrálgico do art. 33. Apesar da pressão da CNBB, a Câmara dos Deputados aprovou o projeto de LDB com uma cláusula impeditiva do uso de recursos públicos no ensino religioso. No Senado, essa cláusula foi suprimida, mas, de volta à Câmara, ela foi reposta, com manifestação ostensiva do líder do PSDB, ${ }^{2}$ Arnaldo Madeira. Além dele, três líderes partidários anunciaram votos favoráveis de suas bancadas ao retorno dessa cláusula ao projeto: Inocêncio de Oliveira, pelo PFL; Lindberg Farias, pelo PCdoB; e Maria Elvira, pelo PMDB.

Mas, quando a lei aprovada foi à sanção presidencial, o contexto político havia mudado significativamente - e para pior, do ponto de vista dos defensores da laicidade do Estado e da educação pública. Nas eleições de 1994, nas quais Fernando Henrique Cardoso - FHC foi eleito presidente da República, não foram reeleitos importantes lideranças do campo educacional, como Hermes Zanetti e Gumercindo Milhomem. Florestan Fernandes, doente, não se candidatou e faleceu no ano seguinte. Enquanto lideranças laicas deixavam o Congresso, foi eleito suplente de deputado, pelo Paraná, Roque Zimermann, o padre Roque, sacerdote católico que veio a ser protagonista da reforma da LDB/96.

\footnotetext{
2- Siglas dos partidos políticos citados no texto: PSDB - Partido da Social Democracia Brasileira; PFL - Partido da Frente Liberal; PCdoB - Partido Comunista do Brasil; PMDB - Partido do Movimento Democrático Brasileiro; PSB - Partido Socialista Brasileiro; PT - Partido dos Trabalhadores; PPB - Partido Progressista Brasileiro; PTB - Partido Trabalhista Brasileiro; PDT Partido Democrático Trabalhista; PSL - Partido Social Liberal; PSD - Partido Social Democrático; PPS - Partido Popular Socialista.
} 
Não bastasse isso, com a eleição de Fernando Henrique Cardoso - FHC, o projeto hegemônico do PSDB previu a mudança da Constituição para permitir a reeleição do presidente. Além da cooptação de partidos para a formação de sua base de sustentação, nos padrões conhecidos do presidencialismo de coalização (ABRANCHES, 1988), a mudança da Constituição se fez mediante procedimentos de compra de votos amplamente divulgados na imprensa. Apesar da indignação de muitos, a instalação de comissões parlamentares de inquérito foi impedida pelos interessados no mesmo processo $^{3}$. Em 28 de janeiro de 1997, a Câmara dos Deputados aprovou a emenda constitucional sobre a reeleição de presidente, governadores e prefeitos. Em 4 de junho do mesmo ano, o Senado aprovou a emenda, imediatamente inserida no texto constitucional por decreto legislativo.

A pressão da Conferência Nacional dos Bispos (Católicos) do Brasil - CNBB, para a supressão da cláusula impeditiva, tinha um componente político-doutrinário, a do Estado manter o ensino religioso nas escolas públicas, já que não era mais possivel à Igreja obrigar os fiéis a matricularem seus filhos nas escolas privadas religiosas, como no passado $;^{4}$ e um componente político-conjuntural, de não menor importância, a terceira visita do papa João Paulo II ao Brasil, para participar de um evento mundial. A entidade realizou sua $34^{\mathrm{a}}$ Assembleia Geral em abril de 1996, cujo foco foi a visita papal, que se realizaria em outubro do ano seguinte, para participar do II Encontro Mundial do Papa com as Famílias. Tratava-se de preparar o evento, mas não só isso. A LDB constava da pauta da reunião dos bipos, sobre a qual eles aprovaram a "Declaração sobre ensino religioso na escola pública”, datada de 22/4/1996. A CNBB preparava a visita e o evento com empenho, e queria mostrar, ao seu líder, eficácia na ação sobre o Estado brasileiro, no que o

3- Reportagem sobre o processo foi publicada em Folha de São Paulo, 13/5/1997.

4- A encíclica Divini illius Magistri, de Pio XI (1929) determinava que "a assistência às escolas acatólicas, neutras ou mistas, quer dizer, abertas indiferentemente a católicos e acatólicos, sem distinção, está proibida às crianças católicas." (Cf: <http://w2.vatican.va/content/pius-xi/pt/encyclicals/ documents/hf_p-xi_enc_31121929_divini-illius-magistri.html>). ensino religioso nas escolas públicas era um ponto importante.

Foi nesse contexto político que a segunda LDB foi sancionada. Em 20 de dezembro de 1996, no mês e dia em que, 35 anos antes, a primeira LDB recebeu sanção do presidente João Goulart, a segunda foi sancionada por FHC. A cerimônia solene no Palácio do Planalto contou com a presença de altos dignatários do governo e do convidado especial, o senador Darcy Ribeiro ${ }^{5}$, que já mostrava os sinais avançados da doença de que veio a falecer daí a um mês e meio. 0 evento foi transmitido por rede nacional de TV.

0 discurso de FHC foi pródigo em elogios ao ministro da Educação Paulo Renato Souza e ao senador Darcy Ribeiro pelos esforços bemsucedidos na produção dessa "lei complexíssima": o ministro e o senador, bem como todo o Congresso, teriam feito o melhor que podiam, mas havia o que alterar.

Há problemas. 0 professor Paulo Renato mencionou um que só veio a mim ontem: a questão complexa, não do ensino religioso, que tem de existir, é assegurado pela Constituição, é facultativo, mas de definir até que ponto cabe ao Estado ou não ter o ônus desse ensino e de que maneira fazê-lo, dada a pluralidade de religiões que existem no Brasil. Essa matéria foi ponderada por nós, aqui, apressada mas duramente, porque sabemos que é preciso dar um encaminhamento. Tal como está, não houve esse encaminhamento, que precisa ser dado respeitando-se a pluralidade e a ecumenicidade, digamos assim, da nossa inspiração em matéria de religiões; e atendendo, também, às condições concretas de diferenciações regionais que existem. (CARDOSO, 1996, p. 704).

0 presidente acusou, implicitamente, o acolhimento da reivindicação da CNBB para o financiamento estatal do ensino religioso nas

5- 0 senador Darcy Ribeiro foi o autor do projeto de LDB que substituiu 0 da Câmara. Bastante emendado, ele acabou sendo a base da lei promulgada. 
escolas públicas 6 , ao mesmo tempo em que apontou o caminho para a mudança da LDB recém-sancionada: alterá-la por outra lei na direção que o ministro Paulo Renato Souza lhe havia encaminhado. No próprio discurso, FHC disse aos presentes, como a todo o país, que a solução melhor era a adotada no estado do Paraná. Bastou o endereço da solução, desnecessário especificá-la.

Se o artigo 33 da LDB fosse vetado, simplesmente, ele deixaria de existir, já que o presidente da República não pode substituir o que o Congresso aprova, apenas suprimir todo o texto ou parte dele. ${ }^{7}$ Sua tática foi sugerir que o próprio Congresso fizesse a substituição, para o que prometia o apoio de sua base política. Ou seja, assim fazendo, ele obteve o mesmo efeito sem evidenciar intromissão direta do Poder Executivo no Legislativo. Foi a isso que chamei de veto transverso: o anúncio público de um convite à mudança da recém-promulgada LDB, com promessa de apoio. 0 governo veio a fazer mais do que convidar o Congresso a corrigir a lei. Para evitar que o projeto lá elaborado entrasse por caminhos indesejados, o Ministério da Educação apresentou o seu próprio, que será focalizado mais adiante.

A imprensa noticiou fartamente 0 propósito de alteração da LDB no tocante ao ensino religioso nas escolas públicas, logo no dia seguinte ao de sua promulgação.

A Folha de São Paulo de 21/12/1996 publicou matéria que mencionava a insatisfação de "diversas facções religiosas, inclusive da Igreja Católica” com o texto da lei. 0 jornal transcreveu a ideia do ministro da Educação de que os estados é que deveriam decidir como ministrar o ensino religioso em seus sistemas de ensino. No seu entender, o procedimento do Paraná é que deveria ser generalizado: o estado paga os salários dos professores de religião que oferecem uma instrução ecumênica aos alunos.

6- Essa pressão foi analisada em Cunha (2014).

7- A supressão tem de ser de todo um artigo, parágrafo, inciso ou letra. A exclusão não pode ser de uma palavra ou oração intercalada, como a que se desejava suprimir - "sem ônus para os cofres públicos".
0 projeto de lei que o ministro prometeu enviar ao Congresso conteria essa solução.

Na mesma data, o Jornal do Brasil, do Rio de Janeiro, disse que o ministro da Educação iria convocar representantes das igrejas para definir novas regras para o ensino religioso nas escolas públicas. 0 resultado dos entendimentos seria transformado em projeto de lei e enviado ao Congresso. As aulas ecumênicas, que estariam sendo ministradas no Paraná, constituiriam um modelo a se levar em conta.

\section{Projetos convergentes na câmara}

0 primeiro a chegar à Câmara foi o projeto 2.757/97, do deputado Nelson Marchezan $^{8}$ (PSDB-RS), em 19/2/1997. Um mês depois, ele foi seguido pelo projeto 2.997/97, do deputado Maurício Requião ${ }^{9}$ (PMDB-PR). Uma semana depois deste, chegou à Câmara dos Deputados o projeto 3.034/97, preparado pelo MEC e enviado pelo presidente da República. Todos tinham em comum a eliminação da expressão sem ônus para o cofres públicos. De acordo com o que determinava o regimento da Câmara, os dois últimos projetos foram apensados ao primeiro a chegar.

Para relatar os projetos, todos oriundos da centro-direita do espectro político, a Comissão de Educação e Cultura da Câmara nomeou um deputado de centro-esquerda, convenientemente, um sacerdote católico, Roque Zimermann, que, aliás, expressava essa ambivalência em seu nome eleitoral: Padre Roque ${ }^{10}$ (PT-PR).

Na Câmara Federal, o padre-deputado adquiriu notoriedade não só por relatar o

8- Com carreira política iniciada no Partido Democrata Cristão, Nelson Marchezan integrou os partidos de apoio à ditadura, chegando a líder do Partido Democrático e Social na Câmara dos Deputados durante o governo do general Figueiredo.

9- Irmão do então senador Roberto Requião, ex-governador do Paraná, 0 deputado Maurício Requião de Melo e Silva é psicólogo formado pela Universidade Federal do Paraná, da qual tornou-se professor.

10- Roque Zimermann teve uma carreira política de brilho intenso e fugaz. Sacerdote da Congregação dos Missionários da Sagrada Família, licenciado em Letras e pós-graduado em Sociologia, integrava o corpo docente da Universidade Estadual de Ponta Grossa. Militante do Partido dos Trabalhadores, foi eleito suplente de deputado federal para a legislatura 1995/98. Veio a assumir o posto duramte 0 afastamento do titular. 
projeto de reforma do artigo 33 da LDB, mas, também, por ter apresentado projeto de lei que determinava a obrigatoriedade do ensino da Sociologia e da Filosofia no ensino médio; e por oferecer projeto de emenda constitucional que instituía a cobrança de contribuição financeira aos ex-alunos de graduação e pós-graduação de universidades públicas. 0 projeto de lei lhe valeu homenagens dos licenciandos daquelas disciplinas, que vislumbravam a ampliação do mercado de trabalho. ${ }^{11}$ Já o projeto de emenda constitucional suscitou a censura dos que defendiam a gratuidade do ensino público para todos e em todos os níveis.

Vejamos cada um dos três projetos de reforma da LDB. 0 de Nelson Marchezan apenas suprimia a expressão sem ônus para os cofres públicos do artigo 33 da $\mathrm{LDB}$, para o que não apresentou justificativa alguma. 0 deputado limitou-se a indicar as vantagens genéricas do ensino religioso para a "plena formação e desenvolvimento do educando", dentre as quais, ressaltou o componente moral e cívico:

Em nossa sociedade, marcada ainda por condutas anti-éticas e amorais, o ensino religioso pode se constituir em elemento capaz de contribuir para o exercício da solidariedade, da tolerância e do respeito mútuo que devem se pautar as relações sociais. (DCD, 22/2/1997, p. 4.849).

0 projeto de Maurício Requião suprimiu explicitamente a modalidade confessional do ensino religioso, constante da versão original da LDB. Com isso, considerou dispensável a restrição ao uso de recursos públicos nessa disciplina. Contraditoriamente ao caráter facultativo do ensino religioso, o deputado não teve dúvida em qualificar essa disciplina como parte integrante da formação básica do cidadão. Pretendia, também, que o conteúdo do ensino religioso fosse definido em parâmetros curriculares nacionais, formulado de comum

11- A propósito, artigo de igual teor do Plano Nacional de Educação, aprovado pelo Congresso Nacional, havia sido vetado pelo presidente FHC. acordo com as diversas denominações religiosas ou entidades que as representassem. Este projeto expressou as demandas do Fórum Nacional Permanente do Ensino Religioso - FONAPER ${ }^{12}$.

A justificativa do projeto encaminhado pelo ministro Paulo Renato Souza ao presidente da República dizia que o ensino religioso deveria ser custeado pelo Poder Público e ministrado sob a responsabilidade de "colegiados interconfessionais”, como já estaria sendo feito em quase todas as unidades da federação (o que não era verdade). Seu projeto criava a modalidade "ensino religioso ecumênico", em substituição às duas modalidades que a versão original da LDB previa (confessional ou interconfessional). Assim, o artigo 19 da Constituição ${ }^{13}$ seria preservado. 0 projeto transferia para os sistemas de ensino as atribuições de definir o conteúdo do ensino inter-religioso, bem como as formas de treinamento, recrutamento e remuneração dos professores. Tais atribuições poderiam ser delegadas, no todo ou em parte, a entidade civil constituída pelas diferentes denominações religiosas. A colaboração das entidades religiosas à educação pública ficaria caracterizada pelo efeito positivo dos valores que elas difundiam para a formação moral dos alunos.

0 projeto de Nelson Marchezan e seus apensados ainda tramitavam pelas comissões da Câmara dos Deputados, quando líderes de partidos e blocos partidários firmaram requerimento, em plenário, solicitando urgência para sua tramitação. Foram eles: Neiva Moreira, líder do Bloco PT/PDT/PCdoB; Aécio Neves, líder do PSDB; Inocêncio Oliveira, líder do PFL; Geddel Vieira Lima, líder do Bloco PMDB/PSL/PSD; e Odelmo Leão, líder do PPB. 0 requerimento foi deferido e, a partir dessa data, 12/6/1997, o projeto tramitou em regime de urgência, atenden-

12- Criado em 1995, por ocasião de reunião do Conselho das Igrejas para o Ensino Religioso, a partir do Grupo de Reflexão Nacional para 0 Ensino Religioso, este da CNBB.

13- Esse artigo veda à União, aos estados, ao Distrito Federal e aos municípios estabelecerem cultos religiosos ou igrejas, subvencioná-los, embaraçar-Ihes o funcionamento ou manter com eles ou seus representantes relações de dependência ou aliança. Fica aberta a exceção para a colaboração de interesse público, na forma da lei. 
do à surpreendente unanimidade partidária, que juntou situação e oposição na tarefa de corresponder à demanda da CNBB de promover um brinde político-ideológico ao papa. A urgência passou a valer para o projeto substitutivo elaborado pelo padre-deputado Roque Zimermann.

Vou reconstruir, brevemente, a discussão do substitutivo a partir do Diário da Câmara dos Deputados, de 18/6/1997, páginas 16.514 a 16.524, que transcreveu as manifestações durante a única sessão em que projeto foi debatido.

A sessão foi presidida pelo deputado Michel Temer $^{14}$ (PMDB-SP). Após introduzir a matéria e anunciar a presença de 356 deputados, o presidente passou a palavra ao relator, que comentou sucintamente cada um dos projetos de lei e justificou seu substitutivo. Extrapolando o conteúdo dos projetos de lei em questão, Zimermann afirmou que eles convergiam ao adotar o princípio de que o ensino religioso é

\section{[...] parte integrante essencial da formação do ser humano como pessoa e cidadão, estando o Estado obrigado a promovê-lo, não só pela previsão de espaço e tempo na grade horária curricular do ensino fundamental público, mas também pelo seu custeio, quando não se reveste de caráter doutrinário ou proselitista, possibilitando aos educandos o acesso à compreensão do fenômeno religioso e ao conhecimento de suas manifestações nas diferentes denominações religiosas. (DCD, 18/6/1997, p. 16.517, grifo meu).}

No entender do padre-deputado, o ensino religioso estaria inserido na hipótese de "colaboração de interesse público" prevista pela Constituição. Ademais, o pagamento dos professores de ensino religioso pelo Estado apoiaria parcerias exitosas que teriam sido

14- A Folha de São Paulo, de $3 / 3 / 2013$, trouxe matéria sobre a Maçonaria, na qual afirma que Michel Temer era o maçom em mais alto posto no Estado brasileiro, que, todavia, não era citado com entusiasmo pelos "irmãos", por parecer "meio inativo". A posição do presidente da Câmara contrastou com o protagonismo da Maçonaria nos debates sobre a primeira LDB. Para uma análise das posições dessa instituição naquele processo, ver Cunha e Fernandes (2012). feitas em "inúmeros (sic) sistemas de ensino estaduais e municipais". Diante disso, já teria sido desencadeado na sociedade brasileira um processo de "correção das distorções históricas". Ele reconheceu que as modalidades confessional e interconfessional previstas na versão original da LDB indicavam que se tratava do ensino de religião. Mas, não era isso que deveria ser ensinado na escola pública. Aqui está o conteúdo que o padre-deputado supôs fazer parte integrante essencial da formação do ser humano como pessoa e cidadão:

Tem como objeto a compreensão da busca do transcendente e do sentido da vida, que dão critérios e segurança ao exercício responsável de valores universais, base da cidadania. Esse processo antecede qualquer opção por uma religião. Não é apenas uma questão de transmissão de meras normas de conduta o que ora se pretende no substitutivo. Trata-se de proporcionar, na educação escolar, oportunidade para que o educando descubra o sentido mais profundo da existência e encontre caminhos e objetivos adequados para sua realização e valores que lhe norteiem o sentido pleno da própria vida. Assim, conferindo-lhe especial dignidade como ser humano e respeito por si mesmo, pelos outros e pela natureza. Trata-se de oferecer ao educando a possibilidade de perceber a transcendência da sua existência e de como isso confere dimensão ao seu ser, nele imprimindo uma marca diferenciada para a construção de uma sociedade mais justa, centrada na solidariedade e na defesa e promoção integral da vida. (DCD, 18/6/1997, p. 16.518)

0 Diário da Câmara dos Deputados não registrou aparte algum a respeito de sua justificativa. Afınal, os valores universais a que o padre-deputado aludia não podem ser atribuídos a sua religião nem a qualquer outra, pois todas disputam quais são eles. 0 sentido profundo da 
existência que ele pretendia que os alunos descobrissem nas aulas de ensino religioso, inclusive a percepção da transcendência de sua existência, foi apresentado como não pertencente ao domínio religioso, como se a imanência não fosse defendida por tradições religiosas diferentes da judaico-cristã. Agnósticos e ateus tampouco poderiam aceitar a doutrina do sacerdote. Essa absurda ideia de um conteúdo não religioso da disciplina ensino religioso, anterior à opção religiosa foi aceita pela maioria dos deputados sem contestação, com se fosse algo evidente ou natural. Também absurda era a ideia de que o ensino religioso faria parte integrante da formação do cidadão. Como os deputados puderam aceitar que alguém que não tivesse tido aulas de religião fosse um cidadão parcial, defeituoso ou insuficiente? Pois era isso que o texto do substitutivo do padre-deputado continha como pressuposto.

Feita a justificativa, Roque Zimermann leu o substitutivo, calcado principalmente no projeto de seu conterrâneo Maurício Requião. 0 padre-deputado esclareceu ter suprimido a expressão "e remuneração" das atribuições dos sistemas de ensino, que havia incorporado do projeto do MEC. Em acordo com vários deputados, a supressão da cláusula restritiva ao uso de recursos públicos foi considerada suficiente para propiciar a remuneração dos agentes do ensino religioso, segundo a fórmula de que o não expressamente proibido é permitido.

\section{Confronto na câmara}

Para discutir o substitutivo, inscreveram-se alguns deputados. Para Gerson Peres (PPB-PA), a alteração da LDB estava sendo feita "de comum acordo com todo o campo religioso do país”, a respeito do que o ministro da Educação teria dialogado com católicos e evangélicos. Em várias passagens de seu discurso, Peres alertou que o ensino religioso não deveria ser confessional nem proselitista. Seu objetivo seria a formação moral do cidadão. Explicitou isso como sendo "o controle moral de suas atividades”, "um freio, uma obstaculização a nossos ímpetos”, assim como
[...] favorecerá o equilíbrio do convívio social, contribuirá para a redução da violência, para o senso crítico das matérias que violentam a moral quer nos meios de comunicação, quer fora deles, quer na licenciosidade explícita hoje em nossa sociedade. (DCD, 18/6/1997, p. 16.520).

0 deputado Inocêncio de Oliveira (PFL-PE) fez um comovente ato de contrição. Apesar de ser experiente parlamentar, e de ter apoiado, em nome de seu partido, o retorno da cláusual impeditiva do uso de recursos públicos no ensino religioso, ele disse ter o Congresso cometido "um equívoco ao excluir o ensino religioso." (DCD, 18/6/1997, p. 16.521) Uma dupla inverdade. Não se tratou de equívoco, pois a matéria foi longamente debatida; nem o ensino religioso foi excluído da LDB/96. Em sua argumentação, além da moral e do civismo, como os colegas precedentes, enfatizou justamente o elemento confessional cristão, que o relator procurava dissimular. Para ele

Trata-se de ensinar procedimentos éticos e morais, o amor à vida, à liberdade, à justiça, o respeito aos direitos humanos e os direitos dos cidadãos. Enfım, é uma aula de filosofia cristã sobre o verdadeiro ensino religioso que deve ser professado. (DCD, 18/6/1997, p. 16.521, grifo meu).

Autor do primeiro projeto de reforma do art. 33 da LDB, o deputado Nelson Marchezan, esmerou-se em elogios ao presidente da República e ao ministro da Educação, os quais teriam contribuído para o entendimento alcançado. Justificou sua própria iniciativa, atropelando a do governo, cuja bancada integrava, como sendo uma correção vinda da própria Câmara, pelo equívoco de ter votado o art. 33 na forma original. Para Marchezan, o objetivo do ensino religioso seria mais laico do que religioso:

Na verdade, ao apresentar esse projeto, o que nos moveu foi a ideia de que para nossa ju- 
ventude o ensino religioso se constituía e se constitui numa base fundamental para a formação humanista, capaz de melhorar a educação, capaz de dar aos formandos elementos novos indispensáveis para uma verdadeira formação humanista, com uma perspectiva de construção de um mundo tolerante, de valorização das opiniões divergentes, para formar uma verdadeira sociedade em que a harmonia, o entendimento e os valores superiores possam vingar e construir uma sociedade menos violenta, menos desumana, mais justa e, por isso mesmo, de melhor qualidade. (DCD, 18/6/1997, p. 16.521).

0 deputado Neiva Moreira (PDT-MA) declarou, brevemente, que a matéria encerrava fatores de ordem religiosa e política, razão pela qual o bloco de oposição integrado por seu partido liberava o voto de seus deputados. Com isso, também os deputados do PT e do PC do B poderiam votar conforme suas convicções ou interesses pessoais.

0 deputado José Genoíno (PT-SP) emitiu a primeira das duas únicas opiniões dissonantes da sessão:

Sr. Presidente, respeito profundamente todos os defensores de religiões nesta Casa, até porque somos um país pluralista neste ponto, mas gostaria de me manifestar contrário ao substitutivo com base na concepção de Estado laico que somos. Há uma definição na lei da formação básica do cidadão, constituindo-se em disciplina regular. Pergunto: e o cidadão que não tem essa ou aquela religião, como vai ser encarado, pelo que diz o caput do artigo modificado ? Como defendo a liberdade de religião, a pluralidade religiosa e o Estado laico, quero registrar minha posição contrária ao substitutivo. (DCD, 18/6/1997, p. 16.522).

Na mesma direção, o deputado Sérgio Arouca (PPS-RJ) declarou:

Sr. Presidente, apoiamos a mesma linha que acabou de ser defendida pelo nobre
Deputado José Genuíno. Defendemos o Estado laico e a liberdade de religião. 0 lugar do ensino religioso é nos templos, nas igrejas. A escola pública deve abrir seu espaço físico para o que seja necessário, inclusive para trabalhos comunitários, para discussão e para o próprio ensino religioso, mas jamais pode ter essa responsabilidade. Defendemos avanços que já foram feitos a partir da Revolução Francesa. Significaria um verdadeiro retrocesso uma nova integração entre Estado e religião. 0 Estado deve ser laico e a religião, livre. Ela não deve ser promovida pelo Estado. Portanto, no sentido de defender o Estado laico e a liberdade de religião, o PPS vota contra esse substitutivo. (DCD, 18/6/1997, p. 16.522).

Em seguida as lideranças partidárias indicaram o voto de suas bancadas. 0 PPS foi o único partido a manifestar posição contrária ao projeto. Manifestaram-se favoráveis o PTB, o PPB, o PSDB, o PSB e o PFL. 0 bloco PT/PDT/ PcdoB liberou o voto. 0 PMDB recomendou 0 voto favorável, mas liberou os deputados para seguirem suas preferências.

Nessa ocasião, a defesa da laicidade do Estado, feita por Genoíno e Arouca, foi contestada pelo deputado paulista Salvador Zimbaldi, que exercia a liderança do PSDB. Assumindo a naturalidade do confessionalismo, disse ele:

Diferentemente daquilo que já foi dito aqui sobre a defesa do Estado laico, entendemos que, na realidade, até o nosso calendário é regido por um ano cristão. Sr. Presidente, entendemos que há divergências entre as ideologias, entre as denominações religiosas, mas há uma convergência em nosso calendário e em nosso dia-a-dia, o próprio Jesus Cristo. (DCD, 18/6/1997, p. 16.523).

Depois de uma rápida votação de expressão passiva (os que estiverem de acordo, permaneçam como se encontram), o presidente da Câmara Michel Temer proclamou a aprovação 
do substitutivo. De nada adiantou o apelo do deputado Arouca para que se verificasse o número de votantes, isto é, a contagem do número dos favoráveis, dos contrários e das abstenções.

Provavelmente, Arouca pretendia obstruir a votação realizada em condições bastante desfavoráveis para a laicidade da educação. Pedir a verificação dos votos daria como resultado o número de presentes e, em consequência, a identificação dos deputados ausentes do plenário. Não foi possível saber quais os deputados efetivamente presentes. ${ }^{15} 0$ Diário da Câmara dos Deputados lista os presentes à sessão, mas não os efetivamente participantes dela. A diferença não foi possível conhecer nas entrevistas que realizei - a documentação é omissa e o tempo decorrido de 17 anos não recomenda confiar na memória dos lá presentes para esse cálculo. Mesmo assim, restou a convicção de que o número dos deputados no plenário era de algumas dezenas, ao invés das três centenas e meia registradas, já que a matéria não tinha a atração do projeto de LDB propriamente dito. Em 1988/96, a atividade parlamentar foi acompanhada de perto pelo Fórum Nacional de Defesa da Escola Pública na $L D B$. Em 1997, ele havia sido desmobilizado, o papa estava de viagem marcada, o projeto de reforma da LDB corria em regime de urgência, e não havia oposição às pressões da CNBB, assumidas pelo presidente da República e sua base de sustentação no Congresso.

Arouca ficou sozinho no pedido de verificação de votos, as outras lideranças não o apoiaram. Ficou valendo a votação pela manifestação passiva. No entanto, seu apelo parece ter suscitado a reação de dois deputados da bancada evangélica, Salatiel Carvalho (PTB-PE) e Lamartine Posella (PPB-SP), que fizeram questão de registrar votos contrários ao substitutivo de padre Roque Zimermann, mas sem apresentar justificativa. E o fizeram em divergência ao que os líderes de seus partidos manifestaram como posição das respectivas bancadas.

A leitura do Diário da Câmara dos Deputados não permite saber quantos foram

15- 0 espírito corporativo e a certeza de reciprocidade impediam a identificação dos ausentes, que deixariam de receber o jeton. os votos favoráveis, contrários, nem se houve alguma abstenção. Dos contrários, sabemos de apenas quatro deputados, dois ex-militantes de partidos comunistas (Genoíno do PCdoB e Arouca do PCB) e dois pastores da Assembleia de Deus (Carvalho e Posella). Mas não sabemos se houve outros. Octavio Eliseo e Arnaldo Madeira, que tinham lutado pela manutenção da cláusula de proibição de uso dos recursos públicos no ensino religioso, tiveram presença registrada na sessão em que ela foi suprimida, sem manifestar-se. Pelo silêncio, sou levado a crer que eles votaram a favor do substitutivo, na direção contrária à que haviam defendido ou não compareceram no plenário.

Tudo somado, a reforma do art. 33 da LDB/96 foi aprovada pela Câmara dos Deputados em regime de urgência, ditada por interesses do campo religioso e suas imbricações com o campo político, mas sem a participação das entidades representativas do campo educacional, que estiveram à margem de sua tramitação. A favor da mudança do art. 33 estiveram os deputados da base de sustentação do governo FHC, aos quais se somaram, provavelmente, os cooptados pela mudança da Constituição em prol da reeleição. A estes se juntaram deputados da oposição, favoráveis ao projeto político da Igreja Católica, inclusive do PT, cujo caso mais ilustrativo foi o próprio relator, padre deputado Roque Zimermann. Difícil é entender a posição do PSB, manifestada por seu líder, o deputado Alexandre Cardoso. A liderança historicamente laica desse partido incluía o deputado Hermes Lima, que combateu o uso de recursos públicos no ensino religioso na Constituinte de 1946; e o deputado Hélio Vianna, autor da emenda que inseriu cláusula impeditiva desse uso, na LDB/61. Igualmente digno de nota foi o silêncio dos quatro deputados do $\mathrm{PCdoB}$ registrados como presentes na sessão, dos quais ignoramos a presença em plenário.

\section{Confronto no senado}

Analogamente ao que fiz com a Câmara, recorri ao Diário do Senado Federal para acompanhar a tramitação do projeto de 
reforma da LDB/96. Como no caso da Câmara, não foi possível saber quantos senadores estavam efetivamente no plenário, dentre os 74 registrados. 0 projeto aprovado na Câmara também tramitou no Senado em regime de urgência. Com idêntica brevidade, foi discutido e aprovado em apenas uma sessão (em 9/7/1997), presidida por Antônio Carlos Magalhães (PFLBA). Houve uma tentativa de emendá-lo, mas ela foi pronta e eficazmente contida, de modo que a tramitação acelerada ficasse garantida.

A emenda foi apresentada pelo senador Abdias Nascimento (PDT-RJ), suplente de Darcy Ribeiro, já falecido. Ele disse ter recebido manifestação da Comissão de Ensino Religioso de Matriz Africana, para quem dois pontos precisariam ser alterados no projeto: (i) antes dos sistemas de ensino definirem conteúdos para o ensino religioso, eles deveriam definir os objetivos educacionais, e (ii) deveria ser suprimida a indução de criação de entidade civil constituida pelas diferentes denominações religiosas, o que representaria uma intromissão indevida do Estado na vida das instituições privadas. No lugar de tal entidade civil, de caráter permanente, seria melhor o recurso a comissões temporárias, que teriam maior flexibilidade e facilitariam o diálogo entre as denominações religiosas.

0 senador Joel de Hollanda (PFL-PE), da Comissão de Constituição e Justiça, relatou favoravelmente ao projeto de lei, em texto que repetiu a argumentação da Câmara, inclusive as vantagens do ensino religioso ecumênico, o que justificaria a supressão do impedimento do uso de recursos públicos para essa disciplina. Mas foi desfavorável à emenda de Abdias Nascimento.

Passemos à discussão, que, apesar de tão curta quanto a da Câmara, foi no Senado mais substanciosa.

Roberto Freire (PPS-PE) abriu a discussão e foi direto ao âmago da questão: o Estado brasileiro é laico, portanto, as escolas públicas não podem oferecer ensino religioso. Não há religião oficial justamente para garantir a liberdade religiosa. 0 ensino religioso é assunto para a igreja e a família. Ao Estado cabe apenas a garantia da liberdade do exercício livre de toda e qualquer religião, uma conquista fundamental da democracia. A Assembleia Nacional Constituinte entendeu diferente, mas a LDB impediu que os custos desse ensino fossem do Estado.

Sentimos a pressão que a $\mathrm{CNBB}$, que representa a Igreja hegemônica no Brasil, exerceu em alguns estados que não queriam ter ônus no pagamento dos professores. A LDB foi sábia. Determinava o caráter facultativo, definia a interconfessionalidade, mas retirava o ônus dos estados, para que as igrejas assumissem uma responsabilidade que é delas e das famílias. Esse projeto é um retrocesso. Vão-se criar problemas sérios com relação às religiões minoritárias que foram discriminadas. Nesse sentido, quero manter a minha visão de escola pública, com todo ônus que isso possa ter. É algo que resgata um pensamento libertário e liberal: um Estado que garanta plena liberdade da cidadania também na questão religiosa. Por isso, com esse encaminhamento, com a responsabilidade que sempre tive de dizer aquilo em que acredito, vou votar contra. (DSF, 9/7/1997, p. 13.453).

Irmão de um dos autores de projeto de reforma da LDB/96, deputado federal pelo mesmo estado e partido, Roberto Requião (PMDB-PR) evocou a existência no município de Curitiba e no Estado do Paraná de conselhos inter-religiosos e o pagamento dos professores da disciplina em questão. Ele foi enfático na aprovação do projeto, inspirado, aliás, na proposta apresentada pelo irmão deputado:

Neste mundo globalizado, em que o neoliberalismo afoga valores éticos e morais, é uma obrigação do Estado dar um conteúdo doutrinário de amor e solidariedade ao ensino público. Acredito que esse projeto será aprovado com facilidade pelo Senado da República, porque é um projeto importante, é um projeto não-conflitante, é um 
projeto que invoca a solidariedade entre os credos religiosos. E essa solidariedade manifesta-se com a presença, neste plenário, de representantes dos cultos afro-brasileiros, da nossa Igreja Católica e das nossas Igrejas Evangélicas. Sem sombra de dúvida, foi imperdoável o fato de, na Lei de Diretrizes e Bases, não ter sido contemplada a questão do professor pago. 0 projeto já tramitou na Câmara dos Deputados e foi aprovado. É importante que ele se consolide neste momento - perdoe-me, senador Abdias Nascimento - sem emendas, para que, de uma vez por todas, todas as escolas brasileiras possam ter contato com o que mais falta no Brasil: a ética e a moral. (DSF, 9/7/1997, p. 13.453).

Requião disse, também, que na experiência curitibana e paranaense, durante suas gestões, os professores não eram do quadro do magistério público, mas terceirizados, contratados pela entidade interconfessional, que os remunerava com os recursos a ela transferidos pelos respectivos governos. Com isso, eles não se tornavam doutrinadores de suas próprias religiões.

Argumentando contra a pressa manifestada pelo senador paranaense, Sebastião Rocha (PDT-AP) declarou-se favorável ao tratamento isonômico dos professores de ensino religioso diante das demais disciplinas, mas, ao mesmo tempo, a favor da emenda de seu colega de partido, Abdias Nascimento. Para ele, dificilmente seria obtido consenso para a formação das entidades civis que seriam ouvidas para a defınição dos conteúdos do ensino religioso.

Eu mesmo recebi aqui, no cafezinho do Senado, juntamente com a senadora Júnia Marise, alguns pastores de certa denominação religiosa que são contrários ao projeto de lei que estamos votando hoje aqui no Senado. Assim, vê-se que, para se constituir uma entidade - e há de ser uma entidade com toda a sua parte cartorial, inclusive, pelo que já está definido no projeto -, no meu entendimento, vai demandar mais tempo do que se se retornasse o projeto à Câmara dos Deputados para essa pequena correção que propõe o senador Abdias Nascimento, a qual não elimina, de forma nenhuma, a exigência de que haja o entendimento entre as várias denominações, o que está previsto também na emenda, só que exclui a necessidade da entidade religiosa. (DSF, 9/7/1997, p. 13.454).

Ao contrário das dúvidas de seu então colega de partido, a gaúcha Emília Fernandes mostrou-se cheia de certezas: quanto à necessidade de se oferecer o ensino religioso nas escolas públicas, do que ela tinha experiência como ex-diretora de escola; de que tal oferecimento implicava custo, o qual tinha de ser assumido pelo Estado; e concluiu sua intervenção no debate pela identificação do ensino religioso com a educação moral e cívica:

[...] a pobreza e o esquecimento de determinados valores são responsabilidade de todos nós. Cada vez mais são esquecidas questões éticas e morais, que são jogadas por terra pela televisão, pelos meios de comunicação. Esses valores precisam ser resgatados. [...] É necessário resgatarmos no ser humano a vontade e o desejo de olhar o mundo não apenas pelos olhos materiais. (DSF, 9/7/1997, p. 13.455)

A senadora Marina Silva (PT-AC), de notória atuação na Assembleia de Deus, trouxe um contraponto ao entusiasmo dos senadores que defendiam ser a religião a base da ética e/ou da moral. Disse a senadora:

[...] não subordino o ensino religioso a uma condição sine qua non para que haja ética na escola e que se discuta a solidariedade. Dentro das religiões e da fé, os princípios da justiça, da ética e da solidariedade estão presentes, não constituindo, no entanto, privilégio nem exclusividade delas, pois pessoas que não têm crença alguma gozam 
desses preceitos e os têm - e é bom que isso fique claro. (DSF, 9/7/1997, p. 13.456).

Para a senadora acreana, a justificativa do ensino religioso residia na discussão da transcendência, que seria fundamental para a existência humana, "até mesmo do meu colega e querido senador Roberto Freire, que transcende este mundo por meio do seu radical compromisso com a justiça social.” (DSF, 9/7/1997, p. 13.456).

Em seguida, outra evangélica tomou a palavras, Benedita da Silva (PT-RJ), também ela membro atuante da Assembleia de Deus. Uma importante dimensão ao debate foi, então, introduzida. A senadora fluminense manifestou-se favorável ao ensino religioso, mas não na forma como o projeto previa. Ela lembrou que na discussão sobre essa matéria na Assembleia Nacional Constituinte, o que se pretendia era a introdução no currículo da História das Religiões, ministrada por professor de História das redes públicas de ensino. Mas, com o passar do tempo, essa demanda se transformou no ensino de religiões na escola pública. Duas dificuldades não poderiam ser escamoteadas. Primeiro, quem seriam os professores? Eles não estavam disponíveis para ensinar todas as religiões existentes, nem mesmo diversas denominações da vertente evangélica. Segundo, não poderia haver uma entidade nacional para tratar da definição dos conteúdos dessa disciplina, no seu entender inviável. Por exemplo, um pentecostal não se sentiria representado por alguém da Igreja Batista ou da Presbiteriana. A emenda de Abdias Nascimento teria, pois, o seu apoio.

Para Benedita da Silva, o professor do ensino religioso só poderia ser pago pelo Estado se ele ensinasse história das religiões. Mas:

[...] se o que queremos é ensino religioso e não história das religiões, cada Igreja poderá contribuir com uma representação e se criará uma comissão para prestar serviços às escolas que assim o desejarem. (DSF, 9/7/1997, p.13.458).
0 senador Gilvam Borges (PMDB-AP) discorreu longamente sobre a impossibilidade de se oferecer o ensino religioso nas escolas públicas, apesar de reconhecer o papel fundamental das religiões na formação do cidadão. Para ele, as religiões seriam importantíssimas. Ao invés de alienantes, como queriam os materialistas, as religiões seriam "uma espécie de muleta importante na salvação do homem, no comportamento ético, na formação moral.” (DSF, 9/7/1997, p. 13.45913.460). No entanto, não haveria como elas serem ensinadas nas escolas públicas. São muitas as religiões e o Estado não poderia discriminar umas em proveito de outras. Caso se pretendesse atender a todas, "vamos encher as escolas públicas de pais-de-santo? Vamos encher escolas de pastores, de padres e de freiras?" (DSF, 9/7/1997, p.13.459). Se o conteúdo dessa disciplina fosse a história das religiões, o senador estaria a favor. Finalizando sua manifestação, o senador amapaense apelou aos colegas para que votassem de acordo com suas convicções, não porque as igrejas poderiam ir contra eles, políticos que eram. "Votem sem medo, votem com seriedade." (DSF, 9/7/1997, p. 13.460).

0 presidente do Senado, Antônio Carlos Magalhães, submeteu o projeto a votação pela forma passiva - os que o aprovam queiram permanecer sentados.

Apenas dois senadores votaram contra: Roberto Freire ${ }^{16}$, ex-militante de partido comunista, e Gilvam Borges, bacharel em Sociologia e radialista de profissão. Também maçom, como o presidente da Câmara, Romeu Tuma, autor da emenda restritiva ao uso de recursos públicos no ensino religioso, quando da tramitação do projeto Darcy Ribeiro de LDB no Senado (CUNHA, 2014), teve sua presença registrada na sessão, mas não pude confirmar se ele estava no plenário. 0 fato é que o Diário do Senado Federal não registrou nenhuma manifestação sua. Se esteve presente,

16- Militante do Partido Comunista Brasileiro por décadas, Roberto Freire ocupava nele o cargo de secretário-geral no momento de sua dissolução, após o que fundou o Partido Popular Socialista. Durante a tramitação do projeto de LDB na Câmara dos Deputados, em sua primeira versão, Freire era deputado pelo PPS de Pernambuco. Quando da reforma da lei, ele era senador pelo mesmo estado e legenda. 
acompanhou a maioria pela aprovação passiva do projeto de reforma.

Por fim, a emenda de Abdias Nascimento foi posta a votos, também na forma passiva. 0 presidente da sessão declarou-a rejeitada, mas o Diário do Senado Federal não registrou os votos favoráveis, desfavoráveis e as eventuais abstenções.

Aprovado nas duas casas do Congresso Nacional, o projeto de lei foi encaminhado ao Presidente da República para sanção. Em 22/7/1997, FHC assinou a lei 9.475, sete meses depois de seu veto transverso à LDB, cujo artigo 33 passou, então, a ter a seguinte redação:

0 ensino religioso, de matrícula facultativa, é parte integrante da formação básica do cidadão e constitui disciplina dos horários normais das escolas públicas de ensino fundamental, assegurado o respeito à diversidade cultural religiosa do Brasil, vedadas quaisquer formas de proselitismo.

Parágrafo $1^{\circ}$ - Os sistemas de ensino regulamentarão os procedimentos para a definição dos conteúdos do ensino religioso e estabelecerão as normas para a habilitação e admissão dos professores.

Parágrafo $2^{\circ}$ - Os sistemas de ensino ouvirão entidade civil, constituída pelas diferentes denominações religiosas para a definição dos conteúdos do ensino religioso.

Concluiu-se, assim, a reforma expedita da segunda LDB, justamente no artigo que tratava da única disciplina mencionada na Constituição brasileira - o ensino religioso nas escolas públicas. 0 cronograma foi apertado, mas a lei foi publicada em tempo: dois meses meses depois da sanção presidencial, o papa João Paulo II desembarcou no Brasil.

\section{Conclusões e hipóteses}

A elaboração da segunda Lei de Diretrizes e Bases da Educação Nacional levou oito anos, mas sua primeira reforma, justamente sobre o artigo que tratava do ensino religioso nas escolas públicas, foi realizada em tempo recorde, apenas seis meses.

Quatro pontos foram objeto dessa reforma em ritmo presto: a qualificação do ensino religioso como parte integrante da formação do cidadão; a supressão do impedimento do uso de recursos públicos no ensino religioso ministrado nas escolas públicas; a transferência aos sistemas estaduais e municipais de ensino, a responsabilidade sobre a normatização referente a essa disciplina, inclusive a do magistério; e a supressão das referências às suas modalidades confessional e interconfessional.

A observação atenta dos protagonistas e respectivas posições, no processo de tramitação, aprovação e sanção presidencial da segunda LDB, bem como de sua reforma, revela um fenômeno político bizarro. Até a aprovação final do projeto de lei pelo Congresso Nacional, a proibição do uso de recursos públicos nessa disciplina foi apoiada pelo plenário da Câmara, mesmo após a supressão dessa restrição pelo Senado.

Tudo mudou no momento da sanção presidencial. Fernando Henrique Cardoso, eleito pela legenda do PSDB, impôs ao texto da lei aprovada no Congresso o que chamei de veto transverso, ao encaminhar a necessidade de mudar o artigo 33 - e justamente para eliminar a proibição de uso de recursos públicos no ensino religioso. A partir de então, houve uma corrida pela reforma da lei, em caráter de urgência, na Câmara e no Senado, seguida de quase unanimidade de apoio ao substitutivo do deputado padre católico Roque Zimermann.

Tamanha unanimidade levou a que as votações fossem praticamente simbólicas, a ponto de não haver registros do número de votos favoráveis, desfavoráveis e abstenções. Deputados mudaram radicalmente de posição, diante do apelo do presidente, fossem eles da situação ou da oposição ao governo. As justificativas para a mudança de posição variaram do pieguismo devoto até a evocação da religião como instrumento de controle individual e social, passando pela confissão 
do que teria sido um equívoco cometido na aprovação da lei. As exceções ficaram por conta de dois ex-militantes de partidos comunistas e dois pastores evangélicos.

Ao proferir o veto transverso, FHC estava forte, o que sugere o exercício, naquele momento, do "presidencialismo imperial" (ABRANCHES, 1988). A Câmara estava a ponto de aprovar a reforma da Constituição para permitir sua reeleição e as denúncias de compra de votos ainda não tinham sido feitas. Mas, FHC estava fraco na imprensa internacional, que divulgava seguidas matérias sobre os graves conflitos agrários no Brasil.

Em 1996/97, o Movimento dos Trabalhadores Rurais sem Terra - MST destacava-se na luta pela reforma agrária e era celebrado ou temido, no país e no exterior, como novidade em termos de ideologia e organização política. (COMPARATO, 2003) Desde a origem, o movimento mantinha fortes vínculos com o clero católico, que, mesmo contido pelo freio papal à Teologia da Libertação e ao engajamento social, apoiava a reforma agrária e o MST, já que o meio rural era onde a Igreja conseguia exercer sua hegemonia com menor resistência dos evangélicos e dos "sem religião", ambos em crescimento nas cidades. Já em 1985, o presidente José Sarney, em visita ao Vaticano, pretendera (e não conseguira) obter do papa manifestação contra o apoio ostensivo do clero ao MST. Embora o governo FHC tivesse aumentado significativamente o número de assentamentos rurais, o movimento pela reforma agrária cresceu ainda mais fortemente em todo o país, anulando o efeito político desse fato.

Naquela conjuntura, dois eventos contribuíram para pôr o MST em evidência no noticiário nacional e internacional durante um tempo demasiadamente longo para as pretensões midiáticas do sociólogo presidente da República: em 17/4/1996, o massacre de Carajás, perpetrado pela Polícia Militar do Pará, de acampados em protesto contra a lentidão no processo de desapropriação de terras para a reforma agrária; e a Marcha a
Brasília, realizada em fevereiro/abril de 1997, seguida de ocupação simultânea de locais de grande movimento em 18 capitais de estados. Nessa marcha, organizações da Igreja Católica ofereceram importante apoio logístico na forma de alimentação e alojamento em paróquias e seminários. A reação conhecida do governo federal foi diversa. De um lado, montou uma rede de monitoramento das ações do MST e desmembrou o Ministério da Agricultura, recriando o Ministério da Reforma Agrária; de outro, o presidente e o ministro passaram a receber dirigentes do movimento para discutir questões em disputa. 0 ministro da Reforma Agrária Raul Jungmann ${ }^{17}$ foi incumbido de prestar informações aos bispos católicos sobre o andamento das atividades governamentais para o setor. Em contrapartida, ouvia as análises dos prelados sobre a questão da terra. Quanto aos partidos políticos, nenhum deles era capaz de dirigir o movimento, nem mesmo os da esquerda do espectro político, transformados todos em espectadores impotentes diante do mais tenso conflito social do país.

Suponho que, naquela conjuntura, a Igreja Católica deveria dispor de um capital político mais expressivo do que a da conjuntura anterior, o que levaria deputados a não afrontarem seus interesses no campo educacional para não perderem o apoio detido ou pretendido por seus partidos ou segmentos de interesse. Mesmo na esquerda, a aprovação da pretensão católica no campo educacional parecia compensar o apoio da Igreja à reforma agrária. 0 senso comum apoiaria essa barganha.

Na oposição, deputados do PT podem ter dado votos, passivamente, ao projeto de reforma do art. 33 da segunda LDB. Não sabemos quantos membros religiosamente afınados desse partido estiveram presentes, de fato, na sessão da Câmara em que o projeto foi discutido. Dois petistas, de posições opostas, estiveram no centro dos acontecimentos: o padre-deputado Roque Zimermann, relator do substitutivo, que

17 - Ex-militante do PCB, então no PPS. 
votou a favor, evidentemente; e José Genoíno, que se manifestou contrário. Duas senadoras petistas se manifestaram: Marina Silva a favor, e Benedita da Silva parcialmente contra, mas a ata registrou o consentimento passivo desta. Dois outros senadores do mesmo partido tiveram presença registrada na ata, mas não sabemos se estavam no plenário no momento da votação. Se estiveram, votaram a favor.

Ao fim e ao cabo, ao reformar a LDB/96, a lei 9.475/97 contribuiu para o estreitamento da autonomia do campo educacional no Brasil. Explicitamente, por qualificar o ensino religioso de parte integrante da formação básica do cidadão, determinação somente aplicável às escolas públicas, afrontando a laicidade do Estado. Implicitamente, pelo silêncio eloquente a respeito do financiamento do ensino religioso nas escolas públicas.

Com efeito, a letra da lei não diz que os professores do ensino religioso tenham de ser ou possam ser pagos pelo Estado, mas o espírito dela, sim, pois foi esse o sentido da manifestação da maioria dos parlamentares. Esse espírito se encarnou em dezenas de leis, decretos e pare- ceres de conselhos de educação das unidades da Federação, concretizando, assim, o apoio político e o financiamento estatal a instituições religiosas, materializando relações de aliança que a Constituição proíbe.

Para os defensores do Estado Laico como equivalente a Estado multi-religioso, a LDB/96 foi aperfeiçoada. Para os que entendiam 0 Estado como imparcial diante das disputas do campo religioso, ela se deteriorou.

Não estamos, contudo, no fim dos tempos. 0 campo político é dinâmico, tanto quanto o campo religioso. Não será surpresa se a demanda de avanço da laicidade do Estado, no sentido próprio do termo, partir do próprio campo religioso, justamente para atenuar seus conflitos internos, nem sempre passíveis de acordo ou dissimulação. Em decorrência, mesmo que os movimentos do campo educacional permaneçam ideologicamente anestesiados, como atualmente, a laicidade das escolas públicas pode vir a ser efetivada pela ação do campo político. Mas, nada impede, ao contrário, tudo recomenda que esses movimentos retomem posições assumidas por esquecidos protagonistas coletivos do campo educacional.

\section{Referências}

ABRANCHES, Sérgio Henrique Hudson de. Presidencialismo de coalizão: 0 dilema institucional brasileiro. Dados: Revista de Ciências Sociais, Rio de Janeiro, v. 31, n. 1, p. 5-32, 1988.

CARDOSO, Fernando Henrique. Discurso de solenidade de sanção da Lei de Diretrizes e Bases da Educação Nacional. In: BRASIL. Presidência da República. Biblioteca da presidência da República. Brasília, DF: Casa Civil, 1996.

COMPARATO, Bruno Konder. A ação política do MST. São Paulo: Expressão Popular, 2003.

CUNHA, Luiz Antônio. Hegemonia e confronto na produção da segunda LDB: o ensino religioso nas escolas públicas. Pro-Posições, Campinas, v. 25, n. 1, p. 141-159, jan./abr. 2014.

CUNHA, Luiz Antônio; FERNANDES, Vânia C. Um acordo insólito: ensino religioso sem ônus para os poderes públicos na primeira LDB. Educação e Pesquisa, São Paulo, v. 38, n. 4, p. 849-864, out./dez. 2012.

DCD. Diário da Câmara dos Deputados. Brasília, DF: Congresso Nacional, 1997.

DSF. Diário do Senado Federal. Brasília, DF: Congresso Nacional, 1997.

Recebido em: 03.05.2015

Aprovado em: 01.09.2015

Luiz Antônio Cunha atua, desde 1997, como professor titular da Universidade Federal do Rio de Janeiro. Tem experiência na área de sociologia, principalmente nos seguintes temas: política educacional, educação brasileira, ensino técnico, história da educação e ensino superior. Desde 2006 a laicidade do Estado constitui seu objeto principal de pesquisa. 